\title{
Sedimentary Record of Polycyclic Aromatic Hydrocarbons from the Shuanglong Catchment, Southwest China
}

\author{
Yu-ping Liu, ${ }^{1}$ Yan-hua Wang, ${ }^{1,2}$ Chun Ye, ${ }^{3}$ Biao Xie, ${ }^{1}$ and Hao Yang ${ }^{1,2}$ \\ ${ }^{1}$ School of Geography Science, Nanjing Normal University, 1 Wenyuan Road, Qixia, Nanjing 210023, China \\ ${ }^{2}$ Jiangsu Center for Collaborative Innovation in Geographical Information Resource Development and Application, Nanjing, China \\ ${ }^{3}$ Centre of Lake Engineering \& Technology, State Key Laboratory of Environmental Criteria and Risk Assessment, \\ Chinese Research Academy of Environmental Sciences, Beijing 100012, China
}

Correspondence should be addressed to Yan-hua Wang; wangyanhua@njnu.edu.cn

Received 27 May 2017; Revised 18 September 2017; Accepted 9 October 2017; Published 13 November 2017

Academic Editor: Andrea Gambaro

Copyright (C) 2017 Yu-ping Liu et al. This is an open access article distributed under the Creative Commons Attribution License, which permits unrestricted use, distribution, and reproduction in any medium, provided the original work is properly cited.

Polycyclic aromatic hydrocarbons (PAHs) in the dated sediments from the Shuanglong catchment in the southwest of China were measured to characterize source inputs. The PAHs concentrations in the priority controlling list of US EPA ( $\sum$ PAHs) ranged within $102.47 \sim 563.24 \mathrm{ng} \mathrm{g}^{-1}$, with an average value of $207.18 \mathrm{ng} \mathrm{g}^{-1}$. The 2-3 rings PAHs were predominant, accounting for $73.77 \%$ of $\sum \mathrm{PAH}$. According to the classification of pollution levels, $\sum$ PAHs concentrations in the sediments are within the range of moderate pollution level. Both the total and individual PAH concentrations changed with the depth. The profile distribution of PAHs concentration in the sediments suggested that PAHs acted as an effective way to reconstruct the historical trends of socioeconomic changes in the study areas. Results of Ant/(Ant + Phe), Fla/(Fla + Pyr), and BaA/(BaA + Chry) show that petroleum and petrogenic matter are attributed to the potential pollution source in the Shuanglong catchment. The coal combustion and incomplete combustion of gasoline and fossil fuel are dominant. TOC contents had positive correlation with $\sum$ PAHs $\left(R^{2}=0.72\right.$, $P<0.001)$, 2-3 rings $\left(R^{2}=0.44, P<0.001\right)$, 4-ring $\left(R^{2}=0.78, P<0.001\right)$, and 5-6 rings $\left(R^{2}=0.62, P<0.001\right)$.

\section{Introduction}

Polycyclic aromatic hydrocarbons (PAHs) are classical persistent organic pollutants (POPs). They are pervasive in the environmental medias, including atmosphere, soil, sediments, plants, and human bodies [1-4]. They have the characteristics of being carcinogenic, teratogenic, and mutagenic. The deposited PAHs may come from anthropogenic activities (burning processes of wood, coal and grass, incomplete combustion of fossil fuels, vehicle emissions, and leakage of crude oil) as well as natural sources (forest fires, volcanic eruptions, and biosynthesis) [5, 6]. As a result of their low solubility and hydrophobicity, PAHs can be easily absorbed by fine particulates once they get into the aquatic environment and accumulate in the sediments with deposition. Therefore, lake sediments and organic matter $(\mathrm{OM})$ are considered as the main fate of PAHs $[7,8]$. As a consequence, PAHs in the sediments are primarily associated with $\mathrm{OM}$ which plays an essential role in affecting the distribution of PAHs $[9,10]$.

Due to their potential toxicity to living organisms, it is urgent to investigate the distributions and potential risks of PAHs. Plenty of studies have been carried out in the surface water and sediments of seas, oceans $[1,5,11-16]$, and atmosphere [17-20], while the food investigations [17, 21] have also been conducted extensively worldwide. However, studies on the small catchment which were affected greatly by the human activities were deficient.

The source and distribution of PAHs are of great environmental significance. Owing to the complicated source of PAHs, difficulties in distinguishing the origins exist. In the past decades, growing attention has been paid to the PAHs environmental behavior. Various tools have been developed to identify the PAHs source [22-27]. Among all the approaches, the Ant/(Ant + Phe), Fla/(Fla + Pyr), BaA/(BaA + Chry), and 


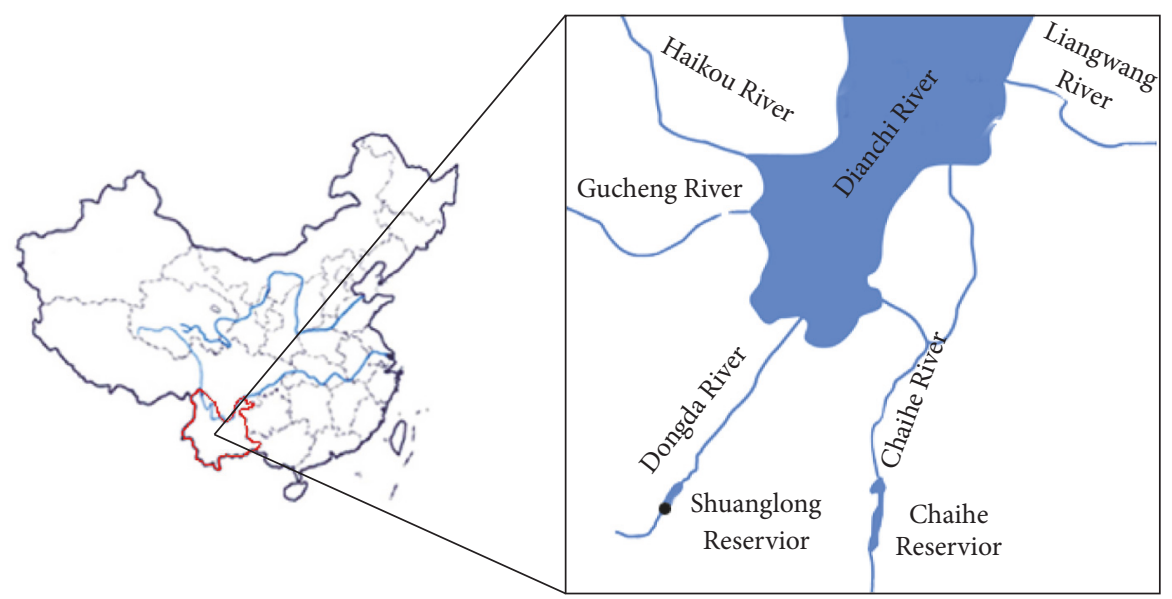

FIGURE 1: Location of sampling sites.

$\mathrm{IcdP} /(\mathrm{IcdP}+\mathrm{BghiP})$ ratios (MDRs) have been applied extensively all over the world [5, 28-31]. Because isomers show substantial intrasource variability and intersource similarity, sources are difficult to be distinguished clearly. Criticism about these indexes exists [32-35]. Even the same sources are not always characterized by the same PAHs emissions profile, and, between different sources, there is significant overlapping in MDRs [36]. They do not respond to know differences in source strength and types between sites (on rural-urban gradients) in atmospheric emission sources [37]. Some researchers $[38,39]$ commented that use of MDRs for sewage sludge PAHs was unfeasible. Even if different sourcesoriginated PAHs took place during the entire wastewater treatment process.

By dating sediment cores [40, 41] and discriminating the source of PAHs via diagnostic rates, the time horizons associated with PAH trends, source variation, and quantification of flux into sediments can be determined. Most PAHs corresponded to the development of industrialization and urbanization. Thus, the profile distribution of PAHs in the sediments could elucidate the relationship between the historical trends of PAHs pollution and the socioeconomic development [42-45]. Many studies have focused on the temporal trends of PAHs in the sediments $[16,46]$. However, investigations on the PAHs historical variation and effects of human activities in the small catchment turned out to be few.

The Dianchi watershed is located in the Yunnan province, southwest of China. Over the past decades, with the development of economic and society, the population grew rapidly and the chemical fertilizer was applied excessively, resulting in serious environmental problems [47, 48]. Recent studies in the Dianchi watershed focused mainly on Dianchi Lake, especially water eutrophication $[49,50]$. However, the PAHs distribution and source identification in the small catchment of the Dianchi watershed are still poorly understood. In order to control the PAHs pollution in the Dianchi watershed, the sedimentary record of PAHs in the small catchment should be focused on. The purpose of this study were as follows: (1) to investigate the pollution level of PAHs in the Shuanglong catchment; (2) to identify the sources of PAHs; (3) to explore the influence factors on PAHs distribution.

\section{Materials and Methods}

2.1. Study Area and Sampling. The Shuanglong Reservoir $\left(24^{\circ} 57^{\prime} \sim 24^{\circ} 59^{\prime} \mathrm{N}, 102^{\circ} 55^{\prime} \sim 102^{\circ} 57^{\prime} \mathrm{E}\right)$ was built in 1956 , belonging to the Dianchi watershed (Figure 1). The Shuanglong catchment is located in the Shuanglong village on the west side of the Kunluo Highway, $70 \mathrm{~km}$ away from the Kunming city. The outflow enters from the south to north through the Dongda River into Dianchi Lake. The elevation is $1933.40 \mathrm{~m}$. The rain collecting area is approximately $54 \mathrm{~km}^{2}$. The main dam of the reservoir is $18.50 \mathrm{~m}$ high, with four auxiliary dams. The total length is $795 \mathrm{~m}$. As the important water source of Jinning County, the capacity of reservoir water storage is 12.16 million $\mathrm{m}^{3}$. In the small catchment, land use types include forest land, abandoned land, residential land, and cultivated land. Diversity of soil types such as red soil, purple soil, alluvial soil, limestone soil, and paddy soil exists. Because of the fertile soil, Jinning County has been regarded as the main producing areas of rice, broad beans, wheat, and rapeseed. Being rich in mineral resources and the well-developed mining industry make Jinning County one of the world's four major phosphorus mining zones. In addition, light industry, food, and building materials and other processing industries are developed.

The sampling time was in June, 2012. All the sampling sites were in the southern of the Shuanglong Reservoir (Figure 1). This region is under less disturbance. According to the principle of uniform distributed, three sediment cores $(70 \mathrm{~cm}$ depth) were collected with self-weight coring equipment. The surface layers ( $2 \mathrm{~cm}$ depth) were taken away to minimize the perturbation of the surface deposited layer. The sediment core was sectioned in $1 \mathrm{~cm}$ intervals immediately. The subsamples were put into plastic bags and then transported to the laboratory instantly and frozen at the temperature of $-50^{\circ} \mathrm{C}$ for $72 \mathrm{~h}$. 
2.2. Dating. The ${ }^{210} \mathrm{~Pb}_{\mathrm{ex}}$ radiometric technique was used with a high-resolution HPGe $\gamma$-spectrometry system (GWL-12015 USA) (for details, see Wang et al., 2013) [51]. The constant CRS model was applied to date the sediment core [52].

2.3. Extraction. Subsamples were lyophilized using a freeze dryer (Eyela FDU-1200, Japan). All freeze-dried samples were ground and passed through the 200-mesh sieve. $200 \pm 2 \mathrm{mg}$ of subsample was weighed. A supersonic apparatus was used for lipid extraction with $50 \mathrm{ml}$ of dichloromethane/hexane $(1: 1, \mathrm{v} / \mathrm{v})$ solution for $1.5 \mathrm{~h}$. Centrifuge for 3 times, moving the upper extraction liquid to the round-bottom flask. The extracts were then concentrated to approximately $2 \mathrm{ml}$ by rotary evaporation. In order to remove the impurities and fractionate, the concentrated extracts went through the anhydrous sodium/silica columns (from bottom to the top, successively filled with $1.5 \mathrm{~g}$ anhydrous sodium, $1.0 \mathrm{~g}$ activated silica gel and $1.5 \mathrm{~g}$ anhydrous sodium) and then eluted with $15 \mathrm{ml}$ mixture of dichloromethane/hexane $(1: 1, \mathrm{v} / \mathrm{v})$ and $5 \mathrm{ml}$ hexane to obtain the PAH fraction. Then eluent was collected in the bottle and concentrated to $0.5 \mathrm{ml}$ by rotary evaporation.

2.4. Analysis Items. The total organic carbon (TOC) concentrations were determined by a TOC analyzer (CSHCN200, Japan). The subsamples were air-dried and ground via a 200-mesh sieve. Each subsample weighted $200 \mathrm{mg}$ into two containers, respectively. One was calcined at $900^{\circ} \mathrm{C}$ for the measurement of total carbon (TC) concentration, and the other was added with phosphoric acid at $200^{\circ} \mathrm{C}$ to measure the inorganic carbon (IC) concentration. Triplicate analyses of every subsample were conducted.

The PAHs identification and quantification were performed through the gas chromatograph-mass spectrometer manufactured by Shimadzu Corporation of Japan (QP2010 ultra, Japan) operating in the electron ionization (EI) mode with a DB-5 fused silica capillary column $(30 \mathrm{~mm} \times 0.25 \mathrm{~mm}$ $\times 0.25 \mu \mathrm{m})$. Splitless injection of $1 \mu \mathrm{l}$ of the subsamples is executed with an autosampler with a temperature of $250^{\circ} \mathrm{C}$, and the high-purity helium (99.999\%) is applied as carrier gas. The temperature of GC oven was programmed initially at the thermostatic of $90^{\circ} \mathrm{C}$ and increased to $180^{\circ} \mathrm{C}$ at the rate of $12^{\circ} \mathrm{C} \mathrm{min}^{-1}$, keeping this condition for $5 \mathrm{~min}$, and then raised to $280^{\circ} \mathrm{C}$ at the rate of $5^{\circ} \mathrm{C} \mathrm{min}^{-1}$, staying for $10 \mathrm{~min}$. The data was collected using a SCAN mode. The qualitative analysis of PAHs is the ratio between relative retention time and the peak intensity of the characteristic fragment ions. The peak area method with 6-point calibration curve was used for quantitative (SIM mode).

\section{Results and Discussion}

3.1. Chronology. The ${ }^{210} \mathrm{~Pb}_{\text {ex }}$ concentrations in the sediment core ranged from 14.31 to $229.35 \mathrm{~Bq} \mathrm{~kg}^{-1}$. The core covers the periods from 1867 to 2011, 144 years of deposition (Figure 2). The average rate of sedimentation was $0.49 \mathrm{~cm}_{\text {year }}{ }^{-1}$, which was similar to the former research in the nearby area [48].

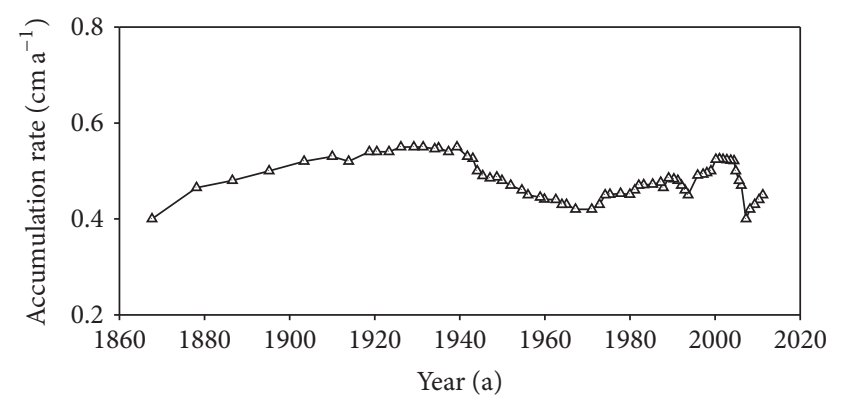

FIGURE 2: Fluctuation of sediment accumulation rate with time by CRS model.

3.2. TOC, TN, and TP Concentrations. The concentrations of TOC, total nitrogen (TN), and total phosphorus (TP) ranged within $0.49 \sim 4.35 \mathrm{~g} \mathrm{~kg}^{-1}$ (mean $1.13 \mathrm{~g} \mathrm{~kg}^{-1}$ ), $0.50 \sim 4.74 \mathrm{~g} \mathrm{~kg}^{-1}$ (mean $1.89 \mathrm{~g} \mathrm{~kg}^{-1}$ ), and $0.10 \sim 0.55 \mathrm{~g} \mathrm{~kg}^{-1}$ (mean $0.28 \mathrm{~g} \mathrm{~kg}^{-1}$ ), respectively (Figure 3). The higher contents of TOC, TN, and TP were detected in the surface layers. Significant negative corrections between depth and TOC $(R=-0.77, P<0.001)$, TN $(R=-0.82, P<0.001)$, and TP $(R=-0.64, P<0.001)$ contents were found. The ratios of carbon to nitrogen $(\mathrm{OC} / \mathrm{N})$ were within the range of $0.43 \sim 1.20$, with a mean value of 0.60 , showing that the organic matter (OM) in the sediments was mainly from the phytoplankton and algae.

3.3. Characteristics of the PAHs Distribution. The concentrations of all 16 PAHs ( $\sum$ PAHs) in the sediments obtained from the Shuanglong catchment ranged from 102.47 to 563.24 $\mathrm{ng} \mathrm{g}^{-1}$, with a mean value of $207.18 \mathrm{ng} \mathrm{g}^{-1}$ (Figure 4). Among the 16 PAHs, the concentrations of less molecular weight (23 rings) (LPAHs) and high molecular weight (4-, 5-, and 6-rings) (HPAHs) varied from 79.82 to $334.19 \mathrm{ng} \mathrm{g}^{-1}$ (mean $152.82 \mathrm{ng} \mathrm{g}^{-1}$ ) and 21.95 to $304.12 \mathrm{ng} \mathrm{g}^{-1}$ (mean $39.65 \mathrm{ng} \mathrm{g}^{-1}$ ), respectively. The LPAHs were predominant, accounting for $47.42 \%$ to $88.84 \%$ (mean $73.77 \%$ ) of the total PAHs. Naphthalene (Nap), in particular, constituted $27.30 \%$ to $62.42 \%$ (mean $36.27 \%$ ) of the total PAHs. On the other hand, in the HPAHs, the proportion of 4-ring PAHs ranged from $3.60 \%$ to $15.00 \%$ (mean 14.47\%), and 5- and 6-ring with a contribution of $4.86 \%$ to $32.33 \%$ (mean $11.76 \%$ ).

Nap contents mainly indicate the source of crude oil and coal [64]. Fluorene (Flu) and Acenaphthene (Ace) are the dominant PAHs in the coke oven [27]. Phenanthrene (Phe), Fluoranthene (Fla), Pyrene (Pyr), and Anthracene (Ant) all usually acted as indicators for coal combustion [27, 65, $66]$. The incomplete burning processes caused by low and medium temperature bring about Phe and Flu [67]. Oil and oil combustion have been regarded as the contributors of Benz[a]anthracene (BaA) and Chrysene (Chry) [66, 68]. Benzo[b]fluoranthene (BbF), Benzo[ghi]perylene (BghiP), and Indeno[1,2,3-cd]pyrene (IcdP) are mainly produced by automobile exhaust $[65,69]$.

The values of $\sum$ PAHs show a rising tendency on the whole. From the bottom $(70 \mathrm{~cm}$ depth, year 1867) to the depth of $16 \mathrm{~cm}$ (year 1998), the concentration of $\sum$ PAHs shows volatile ups and downs. A peak value was obtained in 


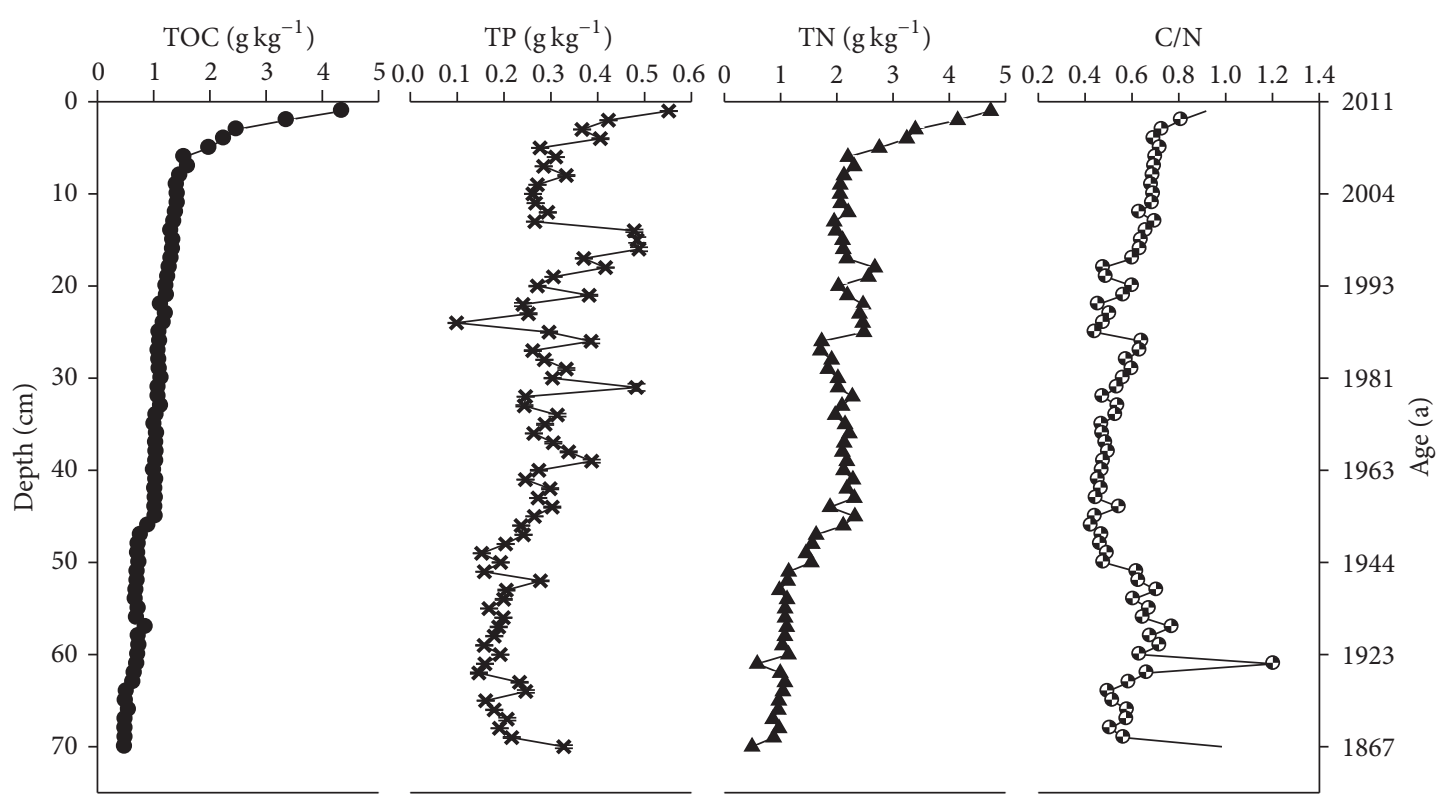

FIGURE 3: Vertical distribution of TOC, TN, TP, and $\mathrm{C} / \mathrm{N}$ in the sediment.

the depth of $29 \mathrm{~cm}$ (year 1982). Because of the Reform and Open Policy implemented in 1978, China has been going a rapid industrialization and urbanization, accompanying the rapid development of Chinese economy. The concentration of $\sum$ PAHs reached to the peak in the year 1982. The $\sum$ PAHs sediment record during the 1983 1992 (from 28 to $21 \mathrm{~cm}$ ) arise steadily. This is in accordance with the fact that the growing population in Yunnan and the expanding industries around the lake. In 1998 (16 cm depth), a large scale of forestry engineering began to be implemented by the government in the Yunnan province. Thus, the concentration of $\sum \mathrm{PAHs}$ decreased in that year. From the depth of $16 \mathrm{~cm}$ (year 1998) to $1 \mathrm{~cm}$ (year 2011), it continued to increase. This can attribute to rapid increase in the amount of civilian vehicles and consequent consumption of petrochemical products beginning in the 1990s. As for individual PAH, the temporal trends in the sediment core are shown in Figure 4. The variations of the Nap, Ace, and Acy concentrations are similar to the $\sum$ PAHs. The Nap distribution shows an upward trend in volatility, representing the crude oil and coke oven for main source of PAHs. A positive shift in the Flu, Ace, and Phe values was observed since the $32 \mathrm{~cm}$ (year 1978), showing a rising tendency of incomplete combustion. The concentrations of Fla, Pyr, and Ant went up slightly from the bottom to the top, indicating the increased coal combusting input. BaA contents grew rapidly since $12 \mathrm{~cm}$ (year 2000). The vertical distribution characteristics of $\mathrm{BaA}$ and Chry exhibit the situation of industrial coal and oil burning contributing much more to the recent PAHs contents. BghiP and IcdP were only detected in the 1-2 cm depth (year 2010 2011) of the sediment, suggesting that the automotive emissions have an important impact on the origin of PAHs in recent years. What is more, this was further confirmed by the evidence of $\mathrm{BbF}$ concentration. The change of the PAH composition in the cores indicates that, throughout a very long period of time, the PAHs flowing into Jinning County were dominated by the biomass burning and domestic coal combustion processes. In recent years, the ever increasing vehicular combustion emission has also contributed a portion of the PAH inputs.

3.4. Assessment of PAHs Pollution. Results of this study show relatively low concentration in the Shuanglong catchment. The pollution levels were in moderate. A comparison with other reports on $\sum$ PAHs in the sediments from different areas are listed in Table 1. The PAH concentrations in the sediments found the same extent to Dongjiang catchment [55], Shilianghe catchment [56], and Baoxianghe catchment [57]. Results in this study appeared much lower than those in Shitou Koumen catchment [58], Yongding catchment [59], and Fenhe catchment [60]. And they were less polluted than Xidayang catchment [61] and Feitsui catchment [62]. However, the sampling sites represented a higher contamination than that in Xiaolangdi catchment [53] and Manwan catchment [54].

3.5. Identification of the PAHs Sources. The determination of PAHs sources is to decrease the input of PAHs to the environment. The deposited PAHs may come from natural and anthropogenic activities. The profile distributions are shown in Figure 5. The ratios of Ant/(Phe + Ant) were in the range of 0.03 to 0.64 with an average of 0.56 , indicating PAHs were mainly derived from pyrogenic materials. These were further confirmed by the ratios of $\mathrm{BaA} /(\mathrm{BaA}+\mathrm{Chry})$ ranging from 0.54 to 0.99 with an average of 0.77 . It can be concluded that coal and biomass combustion were attributed to the major input of PAHs, which was anastomosed with the historical development in this area. Coal was the predominant energy resource and widely used by most of industries and residents in Jinning County. The discrimination of the 

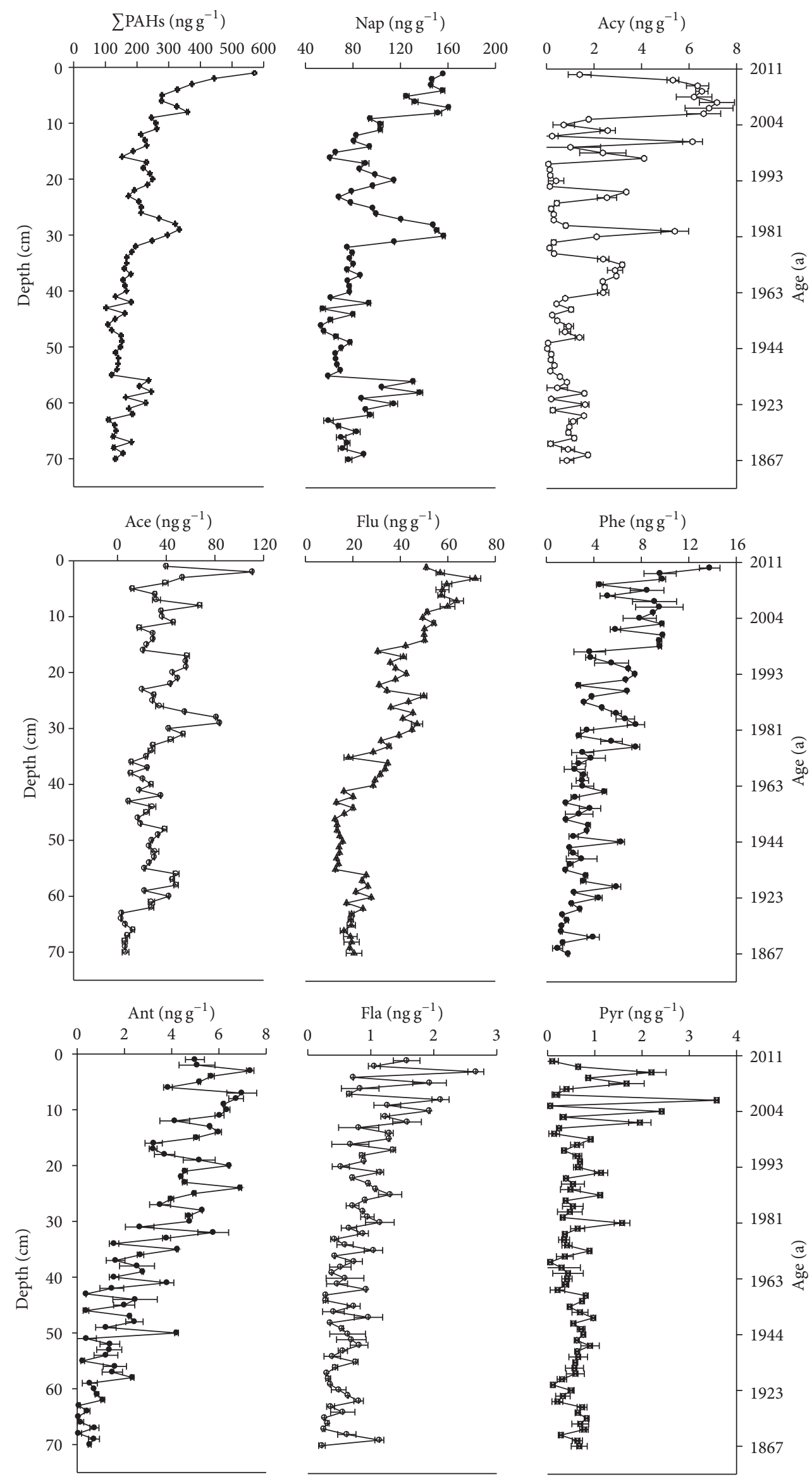

Figure 4: Continued. 

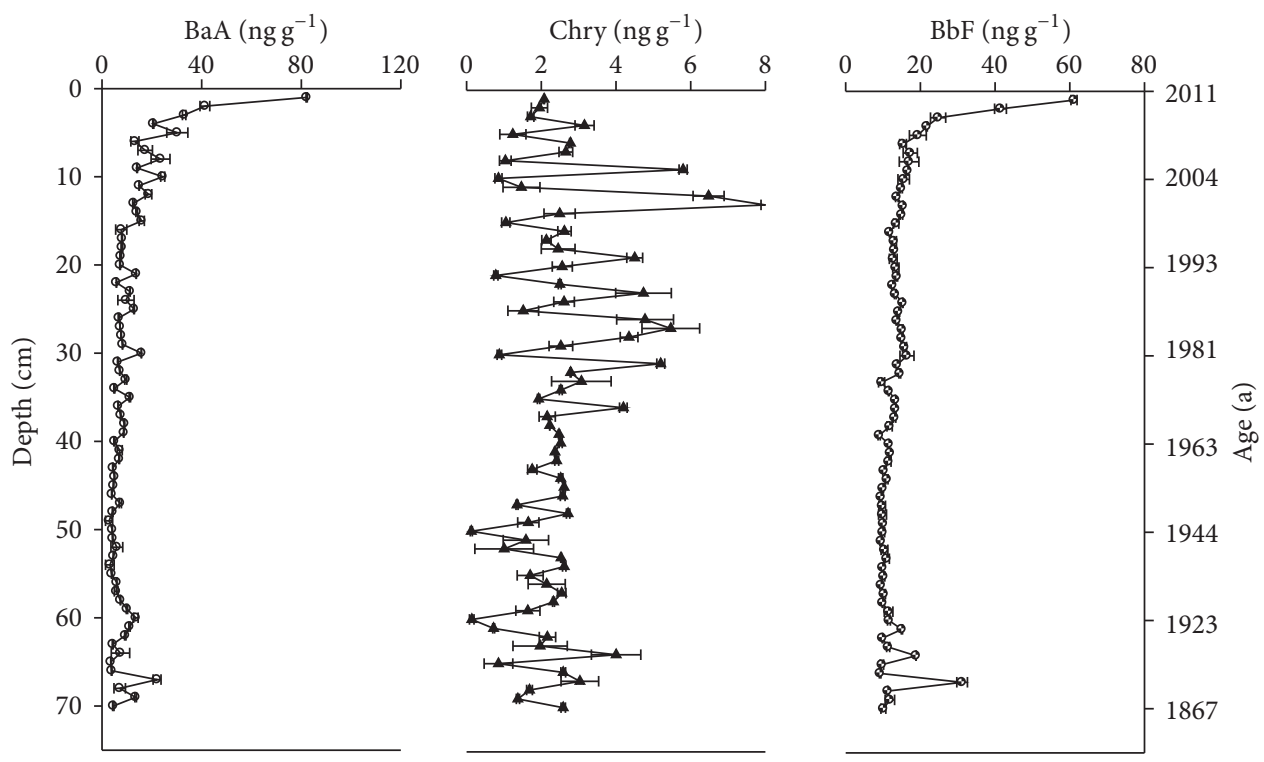

FIGURE 4: Individual concentration in the sediment.
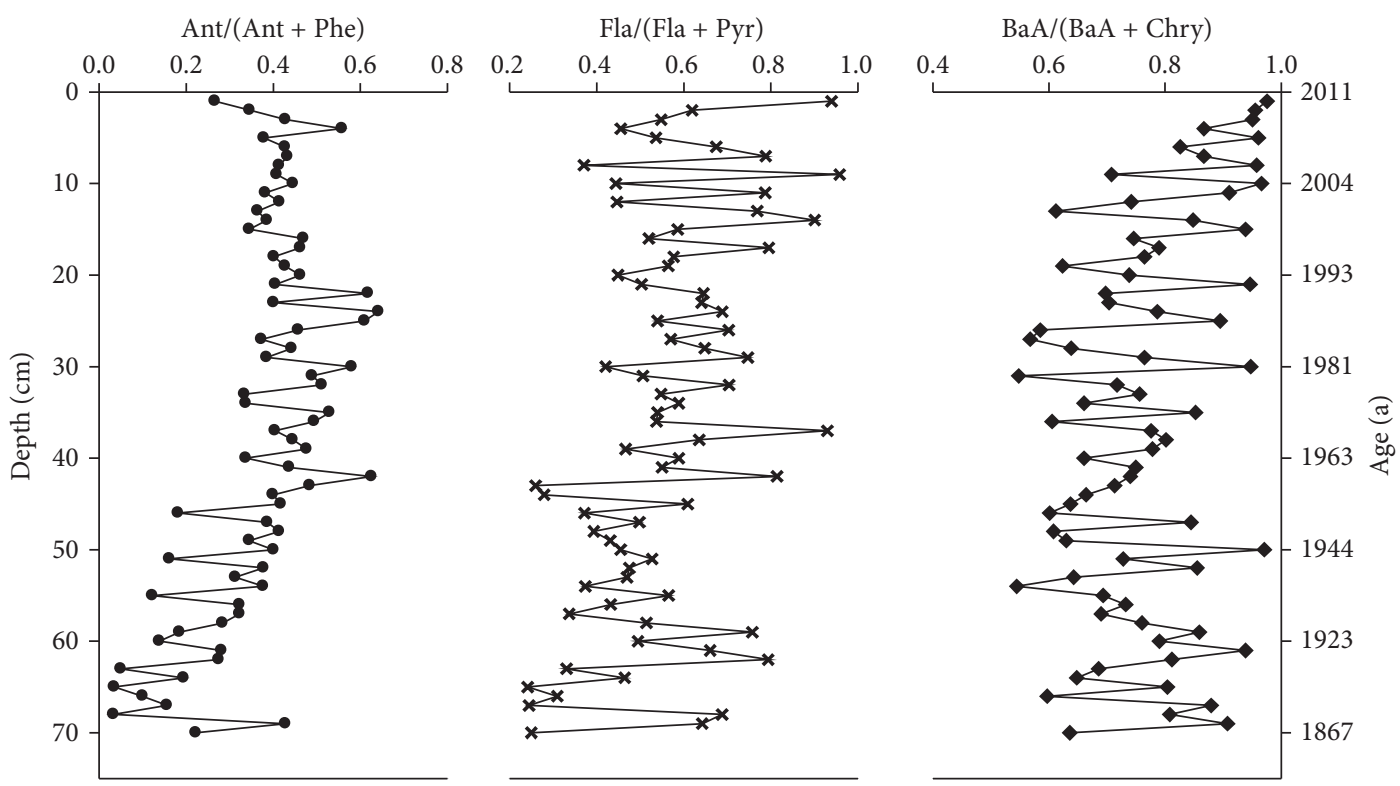

FIgUre 5: Ant/(Phe + Ant), Fla/(Fla + Pyr), and BaA/(BaA + Chry) ratios in the sediment.

TABLE 1: Comparisons of PAHs in different sediments in China.

\begin{tabular}{lccc}
\hline Sampling site & PPHs $\left(\mathrm{ng} \mathrm{g}^{-1}\right)$ & Pollution level $^{\mathrm{a}}$ & References \\
\hline Shuanglong Catchment & $102.47 \sim 563.24$ & Moderate & This study \\
Xiaolangdi Catchment & $98.10 \sim 329.00$ & Low-moderate & {$[53]$} \\
Manwan Catchment & $14.40 \sim 137.70$ & Low-moderate & {$[54]$} \\
Dongjiang Catchment & $85.00 \sim 658.00$ & Low-moderate & {$[55]$} \\
Shilianghe Catchment & $17.37 \sim 839.55$ & Low-moderate & {$[56]$} \\
Baoxianghe Catchment & $162.26 \sim 762.24$ & Moderate & {$[57]$} \\
Shitou Koumen Catchment & $1294.51 \sim 2755.35$ & High & {$[58]$} \\
Yongding Catchment & $1377.00 \sim 2855.00$ & High & {$[59]$} \\
Fenhe Catchment & $539.00 \sim 6218.70$ & Moderate-very high & {$[60]$} \\
Xidayang Catchment & $388.81 \sim 1205.56$ & Moderate-high & {$[61]$} \\
Feitsui Catchment & $236.00 \sim 1197.00$ & Moderate-high & {$[62]$} \\
\hline
\end{tabular}

${ }^{a}$ Pollution levels (Baumard et al. 1998), scale of level of contamination: low: 0 100; moderate: 100 1000; high: 1000 5000; very high: >5000 (Baumard et al. 1998) [63]. 
origins of PAHs was also performed according to the values of $\mathrm{Fla} /(\mathrm{Fla}+\mathrm{Pyr})$. Fla/(Fla + Pyr $)$ ratio vary from 0.24 to 0.96 , showing the mixed inputs of the petroleum and biomass combustion. This deduction was consistent with the former results (Section 3.3). From the depth of $56 \mathrm{~cm}$ to $46 \mathrm{~cm}$ (years 1934 1949), the Fla/(Fla $+\mathrm{Pyr}$ ) ratio is within the range of 0.40 to 0.50 . The average is 0.45 , suggesting that the combustion of liquid fossil fuel and biomass were largely responsible for the input of PAHs. During the 1950s, the ratios of Ant/(Phe + Ant) increased sharply from 0.18 (46 cm depth) to 0.63 (42 cm depth). BaA/(BaA + Chry) ratios were from 0.63 to 0.74 in this period. For Fla/(Fla + Pyr) ratio, a peak value was obtained in the depth of $42 \mathrm{~cm}$ (year 1959), showing a strong contribution of coal and grass combustion. The peak-time period in the 1950s might correspond to the rapid development of the quality of life (including economy and population) in the First Five-Year Plan (1951 1955) after the founding of the China, while from the 1970 s to 1980 s, the values of Ant/(Phe $+\mathrm{Ant}), \mathrm{Fla} /(\mathrm{Fla}+$ $\mathrm{Pyr})$, and $\mathrm{BaA} /(\mathrm{BaA}+\mathrm{Chry})$ are much more than $0.1,0.5$, and 0.35 , respectively. The strong contribution of coal, wood, and grass combustion were deduced. In 1978, the implementation of the "Reform and Open Policy" in China was performed. In particular, during the 2000s, the lower values of Fla/(Fla + Pyr) were found frequently. The liquid fossil fuel was gradually becoming dominant from that time. China's joining the World Trade Organization (WTO) in 2001 may contribute greatly. On the other hand, due to the development of tourism in the surrounding area, the vehicle emission flux is increasing. Thus the incomplete combustion of gasoline and fossil fuel became more and more predominant sources of PAHs year by year. The petrogenic sources may be interpreted to the scour of rainwater. The street dust which potentially contains petrogenic PAHs (spilled fuel, asphalt, and tire-wear materials) may enter into the water body and finally get into the sediments.

3.6. Effects of the Organic Matter Transportation on the PAHs Distribution. With respect to the relationship between the contents of PAHs and TOC, many researches had been conducted. It turned out to be a positive linear relationship between PAHs and TOC contents [1, 62]. The sediments are rich in organic matter $(\mathrm{OM})$, which has a complex pore structure. The pore structure has a fast absorbed outer surface and a slowly absorbed inner surface, making it easily absorb the PAHs. As a result, OM became the storage depot of PAHs. PAHs migrate along with the sediment particles, so the TOC was affected significantly on the distribution of PAHs in the sediment core. The higher contents of TOC corresponded with the higher value of PAHs.

In this study, the relationship between the contents of TOC and PAHs are shown in Figure 6. TOC contents had positive correlation with $\sum$ PAHs $\left(R^{2}=0.72, P<0.001\right), 2-3$ rings $\left(R^{2}=0.44, P<0.001\right)$, 4-ring $\left(R^{2}=0.78, P<0.001\right)$, and 5-6 rings $\left(R^{2}=0.62, P<0.001\right)$. HPAHs have the characteristics of being strongly lipophilic and hard-degraded. Therefore, HPAHs may be adsorbed by TOC easily. While LPAHs are relatively more volatile and soluble. Obviously, the

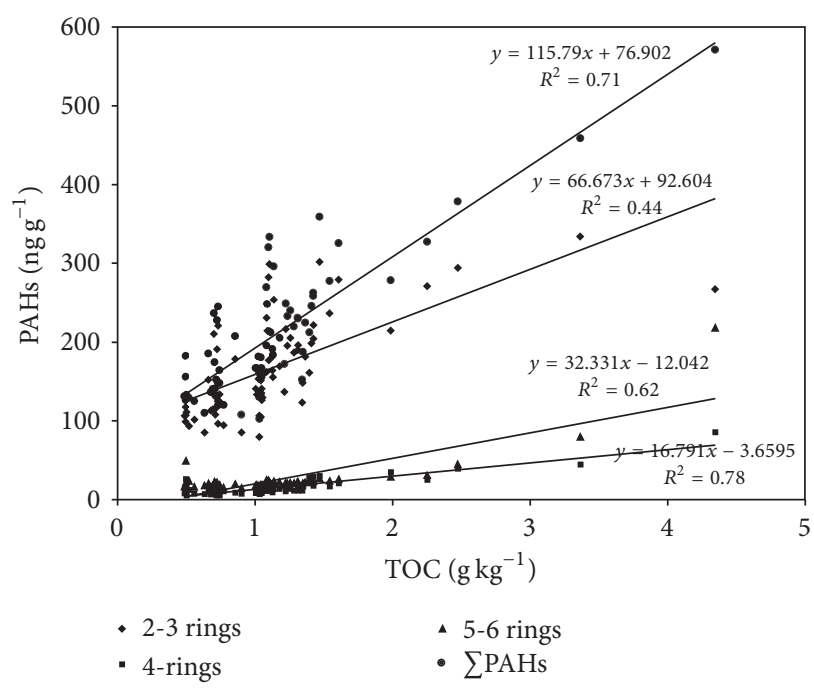

Figure 6: Relationship between TOC and PAHs concentrations.

correlation between TOC contents and higher PAHs contents is much higher than that of the lower ones. TOC contents played more contribution in controlling HPAHs than LPAHs.

\section{Conclusions}

In this study, the PAHs distributions, sources identification, and influence factors analysis in the Shuanglong catchment of the Dianchi watershed were investigated. Based on the results we obtained the following conclusions:

(1) The $\sum$ PAHs concentrations ranged from 102.47 to $563.24 \mathrm{ng} \mathrm{g}^{-1}$, reflecting a moderate pollution level. The $\sum$ PAHs compositions were dominated by 2-3 rings PAHs. As for individual $\mathrm{PAH}$, Nap, Ace, Flu, $\mathrm{BaA}$, and $\mathrm{BaF}$ were main components.

(2) Based on the molecular indices (Ant/(Phe + Ant), $\mathrm{Fla} /(\mathrm{Fla}+\mathrm{Pyr})$, and $\mathrm{BaA} /(\mathrm{BaA}+\mathrm{Chry}))$, it was suggested that the sedimentary PAHs contents in the Shuanglong catchment were dominated by the coal combustion and petrogenic materials.

(3) Significantly positive correlations between TOC and HPAHs indicated that TOC played a more important role in controlling the distributions of HPAHs than LPAHs in sediments of the Shuanglong catchment.

\section{Conflicts of Interest}

The authors declare that there are no conflicts of interest regarding the publication of this paper.

\section{Acknowledgments}

This work was supported by the "973" Project (2014CB953801), the National Natural Science Foundation of China (41673107), and Qing Lan Project (184080H20181 and 184080H10330). 


\section{References}

[1] S.-M. Zhao, B. Wang, D.-W. Wang et al., "Environmental behavior of PAHs in Dianchi Lake distributions, sources and risk assessment of polycyclic aromatic hydrocarbons in surface sediments from Dianchi Lake, China," International Journal of Environmental Research, vol. 8, no. 2, pp. 317-328, 2014.

[2] F. Kanzari, A. D. Syakti, L. Asia et al., "Distributions and sources of persistent organic pollutants (aliphatic hydrocarbons, PAHs, PCBs and pesticides) in surface sediments of an industrialized urban river (Huveaune), France," Science of the Total Environment, vol. 478, pp. 141-151, 2014.

[3] K. C. Cheung, H. M. Leung, K. Y. Kong, and M. H. Wong, "Residual levels of DDTs and PAHs in freshwater and marine fish from Hong Kong markets and their health risk assessment," Chemosphere, vol. 66, no. 3, pp. 460-468, 2007.

[4] X. Luo, B. Mai, Q. Yang, J. Fu, G. Sheng, and Z. Wang, "Polycyclic aromatic hydrocarbons (PAHs) and organochlorine pesticides in water columns from the Pearl River and the Macao harbor in the Pearl River Delta in South China," Marine Pollution Bulletin, vol. 48, no. 11-12, pp. 1102-1115, 2004.

[5] J.-Y. Guo, F.-C. Wu, H.-Q. Liao et al., "Sedimentary record of polycyclic aromatic hydrocarbons and DDTs in Dianchi Lake, an urban lake in Southwest China," Environmental Science and Pollution Research, vol. 20, no. 8, pp. 5471-5480, 2013.

[6] M. Saha, A. Togo, K. Mizukawa et al., "Sources of sedimentary PAHs in tropical Asian waters: differentiation between pyrogenic and petrogenic sources by alkyl homolog abundance," Marine Pollution Bulletin, vol. 58, no. 2, pp. 189-200, 2009.

[7] J. E. Djomo, A. Dauta, V. Ferrier et al., "Toxic effects of some major polyaromatic hydrocarbons found in crude oil and aquatic sediments on Scenedesmus subspicatus," Water Research, vol. 38, no. 7, pp. 1817-1821, 2004.

[8] P. E. T. Douben, "An overview of the partitioning and bioavailability of PAHs in sediments and soils," in PAHs: An Ecotoxicological Perspective, Chapter 7, pp. 97-126, John Wiley \& Sons, Ltd, 2003.

[9] M. J. Salloum, B. Chefetz, and P. G. Hatcher, "Phenanthrene sorption by aliphatic-rich natural organic matter," Environmental Science \& Technology, vol. 36, no. 9, pp. 1953-1958, 2002.

[10] F. Wu, L. Xu, Y. Sun, H. Liao, X. Zhao, and J. Guo, "Exploring the relationship between polycyclic aromatic hydrocarbons and sedimentary organic carbon in three Chinese lakes," Journal of Soils and Sediments, vol. 12, no. 5, pp. 774-783, 2012.

[11] J. Liu, Y. Xu, J. Li et al., "The distribution and origin of pahs over the asian marginal seas, the indian, and the pacific oceans: Implications for outflows from Asia and Africa," Journal of Geophysical Research: Atmospheres, vol. 119, no. 4, pp. 1949-1961, 2014.

[12] E. Nasher, L. Y. Heng, Z. Zakaria, and S. Surif, "Concentrations and sources of polycyclic aromatic hydrocarbons in the seawater around Langkawi Island, Malaysia," Journal of Chemistry, vol. 2013, Article ID 975781, 10 pages, 2013.

[13] Y. Tian, T.-L. Zheng, X.-H. Wang, Q.-J. Xiao, and Y. Zhang, "PAHs Concentration and PAHs-degrading bacteria in surface water of sea area to the west of Xiamen," Journal of Tropical Oceanography, 2003.

[14] Y.-L. Wu, X.-H. Wang, Y.-Y. Li, and H.-S. Hong, "Occurrence of polycyclic aromatic hydrocarbons (PAHs) in seawater from the Western Taiwan Strait, China," Marine Pollution Bulletin, vol. 63, no. 5-12, pp. 459-463, 2011.
[15] Z. Tang, J. Guo, H. Liao et al., "Spatial and temporal distribution and sources of polycyclic aromatic hydrocarbons in sediments of Taihu Lake, eastern China," Environmental Science and Pollution Research, vol. 22, no. 7, pp. 5350-5358, 2015.

[16] J. Weng, S. Li, T. Wang, X. Zhu, R. Chen, and L. Wang, "Distribution of petroleum hydrocarbons in sediments from Dianchi Lake, China," Environmental Earth Sciences, vol. 75, no. 6, pp. $1-9,2016$.

[17] O. S. Fatoki, B. J. Opeolu, and B. O. Ximba, "Polycyclic aromatic hydrocarbons (PAHs) in food and environmental samples: an overview," Fresenius Environmental Bulletin, vol. 20, no. 8 A, pp. 2012-2020, 2011.

[18] S. Sun, Z. Xia, T. Wang et al., "Pollution level, sources, and lung cancer risk of PM10-bound polycyclic aromatic hydrocarbons (PAHs) in summer in Nanjing, China," Journal of Chemistry, vol. 2016, Article ID 4546290, 10 pages, 2016.

[19] N. Vardar, Y. Tasdemir, M. Odabasi, and K. E. Noll, "Characterization of atmospheric concentrations and partitioning of PAHs in the Chicago atmosphere," Science of the Total Environment, vol. 327, no. 1-3, pp. 163-174, 2004.

[20] P.-J. Tsai, H.-Y. Shieh, W.-J. Lee, and S.-O. Lai, "Characterization of PAHs in the atmosphere of carbon black manufacturing workplaces," Journal of Hazardous Materials, vol. 91, no. 1-3, pp. 25-42, 2002.

[21] G. Li, S. Wu, L. Wang, and C. C. Akoh, "Concentration, dietary exposure and health risk estimation of polycyclic aromatic hydrocarbons (PAHs) in youtiao, a Chinese traditional fried food," Food Control, vol. 59, pp. 328-336, 2016.

[22] D. D. Golobočanin, B. D. Škrbić, and N. R. Miljević, "Principal component analysis for soil contamination with PAHs," Chemometrics and Intelligent Laboratory Systems, vol. 72, no. 2, pp. 219223, 2004.

[23] F. Jacquot, N. Pieri, P. Doumenq et al., "Classification of sediment samples from brittany coast 14 years after tanio oil spill based on GC/MS analysis of PAHs and principal component analysis," Polycyclic Aromatic Compounds, vol. 9, no. 1-4, pp. 101108, 1996.

[24] H. Yuan, T. Li, X. Ding, G. Zhao, and S. Ye, "Distribution, sources and potential toxicological significance of polycyclic aromatic hydrocarbons (PAHs) in surface soils of the Yellow River Delta, China," Marine Pollution Bulletin, vol. 83, no. 1, pp. 258-264, 2014.

[25] X.-M. Lin, J.-L. Chen, W.-X. Liu, Y.-F. Duan, and S. Tao, "Source identification of PAHs in surface sediments from Bohai Sea by multivariate statistics," Marine Environmental Science, vol. 26, no. 2, pp. 107-111, 2007.

[26] G. Liu, R.-T. Bi, S.-J. Wang, W.-X. Wei, F.-S. Li, and G.-L. Guo, "Statistical characteristic analysis of soil PAHs in a coking contaminated site of China," Chinese Journal of Applied Ecology, vol. 24, no. 6, pp. 1722-1728, 2013.

[27] M. F. Simcik, S. J. Eisenreich, and P. J. Lioy, "Source apportionment and source/sink relationships of PAHs in the coastal atmosphere of Chicago and Lake Michigan," Atmospheric Environment, vol. 33, no. 30, pp. 5071-5079, 1999.

[28] J. Jautzy, J. M. E. Ahad, C. Gobeil, and M. M. Savard, “Centurylong source apportionment of PAHs in athabasca oil sands region lakes using diagnostic ratios and compound-specific carbon isotope signatures," Environmental Science \& Technology, vol. 47, no. 12, pp. 6155-6163, 2013.

[29] A. Katsoyiannis and K. Breivik, "Model-based evaluation of the use of polycyclic aromatic hydrocarbons molecular diagnostic 
ratios as a source identification tool," Environmental Pollution, vol. 184, pp. 488-494, 2014.

[30] Y.-H. Lang, X. Yang, H. Wang, W. Yang, and G.-L. Li, "Diagnostic ratios and positive matrix factorization to identify potential sources of PAHS in sediments of the Rizhao Offshore, China," Polycyclic Aromatic Compounds, vol. 33, no. 2, pp. 161-172, 2013.

[31] G. Q. Liu, G. Zhang, X. D. Li, J. Li, X. Z. Peng, and S. H. Qi, "Sedimentary record of polycyclic aromatic hydrocarbons in a sediment core from the Pearl River Estuary, South China," Marine Pollution Bulletin, vol. 51, no. 5-12, pp. 912-921, 2005.

[32] M. B. Yunker, R. W. Macdonald, R. Vingarzan, R. H. Mitchell, D. Goyette, and S. Sylvestre, "PAHs in the Fraser River basin: a critical appraisal of PAH ratios as indicators of PAH source and composition," Organic Geochemistry, vol. 33, no. 4, pp. 489-515, 2002.

[33] X. L. Zhang, S. Tao, W. X. Liu, Y. Yang, Q. Zuo, and S. Z. Liu, "Source diagnostics of polycyclic aromatic hydrocarbons based on species ratios: a multimedia approach," Environmental Science \& Technology, vol. 39, no. 23, pp. 9109-9114, 2005.

[34] A. Dvorská, G. Lammel, and J. Klánová, "Use of diagnostic ratios for studying source apportionment and reactivity of ambient polycyclic aromatic hydrocarbons over Central Europe," Atmospheric Environment, vol. 45, no. 2, pp. 420-427, 2011.

[35] M. S. Alam, J. M. Delgado-Saborit, C. Stark, and R. M. Harrison, "Using atmospheric measurements of $\mathrm{PAH}$ and quinone compounds at roadside and urban background sites to assess sources and reactivity," Atmospheric Environment, vol. 77, pp. 24-35, 2013.

[36] E. Galarneau, "Source specificity and atmospheric processing of airborne PAHs: implications for source apportionment," Atmospheric Environment, vol. 42, no. 35, pp. 8139-8149, 2008.

[37] A. Katsoyiannis, A. J. Sweetman, and K. C. Jones, "PAH molecular diagnostic ratios applied to atmospheric sources: A critical evaluation using two decades of source inventory and air concentration data from the UK," Environmental Science \& Technology, vol. 45, no. 20, pp. 8897-8906, 2011.

[38] A. Katsoyiannis, E. Terzi, and Q.-Y. Cai, "On the use of PAH molecular diagnostic ratios in sewage sludge for the understanding of the PAH sources. Is this use appropriate?" Chemosphere, vol. 69, no. 8, pp. 1337-1339, 2007.

[39] Q.-Y. Cai, C.-H. Mo, Y.-H. Li et al., "Occurrence and assessment of polycyclic aromatic hydrocarbons in soils from vegetable fields of the Pearl River Delta, South China," Chemosphere, vol. 68, no. 1, pp. 159-168, 2007.

[40] W. Wilcke, M. Krauss, G. Safronov, A. D. Fokin, and M. Kaupenjohann, "Polycyclic aromatic hydrocarbons (PAHs) in soils of the Moscow region - Concentrations, temporal trends, and small-scale distribution," Journal of Environmental Quality, vol. 34, no. 5, pp. 1581-1590, 2005.

[41] J. Xu, J.-Y. Guo, G.-R. Liu et al., "Historical trends of concentrations, source contributions and toxicities for PAHs in dated sediment cores from five lakes in western China," Science of the Total Environment, vol. 470-471, pp. 519-526, 2014.

[42] A. O. Barakat, A. Mostafa, T. L. Wade, S. T. Sweet, and N. B. El Sayed, "Spatial distribution and temporal trends of polycyclic aromatic hydrocarbons (PAHs) in sediments from Lake Maryut, Alexandria, Egypt," Water, Air, \& Soil Pollution, vol. 218, no. 1-4, pp. 63-80, 2011.

[43] J. Chen, X.-J. Wang, and S. Tao, "The influences of soil total organic carbon and clay contents on PAHs vertical distributions in soils in Tianjin area," Research of Environmental Sciences, vol. 18, no. 4, pp. 79-83, 2005.

[44] T. Fukushima, S. Watanabe, K. Kamiya, and N. Ozaki, "Vertical distributions of PAHs in the sediments of four lakes in Japan," Journal of Soils and Sediments, vol. 12, no. 10, pp. 1530-1540, 2012.

[45] W. Guo, Y. Pei, Z. Yang, and H. Chen, "Historical changes in polycyclic aromatic hydrocarbons (PAHs) input in Lake Baiyangdian related to regional socio-economic development," Journal of Hazardous Materials, vol. 187, no. 1-3, pp. 441-449, 2011.

[46] S. Giuliani, R. Piazza, B. El Moumni et al., "Recognizing different impacts of human and natural sources on the spatial distribution and temporal trends of PAHs and PCBs (including PCB-11) in sediments of the nador lagoon (Morocco)," Science of the Total Environment, vol. 526, pp. 346-357, 2015.

[47] D.-B. Huang, H.-P. Bader, R. Scheidegger, R. Schertenleib, and W. Gujer, "Confronting limitations: New solutions required for urban water management in Kunming City," Journal of Environmental Management, vol. 84, no. 1, pp. 49-61, 2007.

[48] Y. Wang, H. Yang, J. Zhang, M. Xu, and C. Wu, "Biomarker and stable carbon isotopic signatures for 100-200 year sediment record in the Chaihe catchment in southwest China," Science of the Total Environment, vol. 502, pp. 266-275, 2015.

[49] L.-N. Du, Y. Li, X.-Y. Chen, and J.-X. Yang, "Effect of eutrophication on molluscan community composition in the Lake Dianchi (China, Yunnan)," Limnologica, vol. 41, no. 3, pp. 213-219, 2011.

[50] Y. Liu, P. Yang, H. Sheng et al., "Watershed pollution prevention planning and eutrophication control strategy for Lake Dianchi," Acta Scientiae Circumstantiae, vol. 32, no. 8, pp. 1962-1972, 2012.

[51] Y.-H. Wang, H. Yang, X. Chen et al., "Molecular biomarkers for sources of organic matter in lacustrine sediments in a subtropical lake in China," Environmental Pollution, vol. 176, pp. 284-291, 2013.

[52] P. G. Appleby and F. Oldfieldz, "The assessment of $210 \mathrm{~Pb}$ data from sites with varying sediment accumulation rates," Hydrobiologia, vol. 103, no. 1, pp. 29-35, 1983.

[53] J. Dong, X. Xia, M. Wang et al., "Effect of water-sediment regulation of the Xiaolangdi Reservoir on the concentrations, bioavailability, and fluxes of PAHs in the middle and lower reaches of the Yellow River," Journal of Hydrology, vol. 527, pp. 101-112, 2015.

[54] N. N. An, S. Liu, Y. Yin, F. Cheng, S. Dong, and X. Wu, "Spatial distribution and sources of polycyclic aromatic hydrocarbons (PAHs) in the reservoir sediments after impoundment of Manwan Dam in the middle of Lancang River, China," Ecotoxicology, vol. 25, no. 6, pp. 1072-1081, 2016.

[55] L. Yan, P. K. Fung, F. T. Man, C.-H. Hua, and H.-W. Ming, "Sources and seasonal variation of PAHs in the sediments of drinking water reservoirs in Hong Kong and the Dongjiang River (China)," Environmental Monitoring \& Assessment, vol. 146, no. 1-3, pp. 41-50, 2008.

[56] R. Zhang, F. Zhang, M. Guan, Y. Shu, and T. Li, "Sources and chronology of combustion-derived pollution to Shilianghe Reservoir, eastern China: Evidences from PAHs profiles, As, $\mathrm{Hg}$, $\mathrm{Pb}$ and $\mathrm{Pb}$ isotopes," Catena, vol. 149, pp. 232-240, 2017.

[57] P. Sun, B. Xie, D. Zhou, Y. Song, and H. Yang, "Vertical profile and sources of polycyclic aromatic hydrocarbons in a sediment core from Baoxianghe Reservoir in Dianchi Watershed," Acta Scientiae Circumstantiae, vol. 36, no. 10, pp. 3615-3622, 2016.

[58] C. Sun, J. Zhang, Q. Ma, F. Zhang, and Y. Chen, "Risk assessment of polycyclic aromatic hydrocarbons (PAHs) in sediments from 
a mixed-use reservoir," Human and Ecological Risk Assessment, vol. 22, no. 2, pp. 447-459, 2015.

[59] S.-B. Huang, Z.-J. Wang, Y.-P. Xu, and M. Ma, "Distribution, sources and potential toxicological significance of polycyclic aromatic hydrocarbons (PAHs) in Guanting Reservoir sediments, China," Journal of Environmental Sciences, vol. 17, no. 1, pp. 48-53, 2005.

[60] W.-H. Li, Y.-Z. Tian, G.-L. Shi, C.-S. Guo, X. Li, and Y.-C. Feng, "Concentrations and sources of PAHs in surface sediments of the Fenhe reservoir and watershed, China," Ecotoxicology and Environmental Safety, vol. 75, no. 1, pp. 198-206, 2012.

[61] J. Zhao, H. Zhou, G. Fu et al., "Distributions, sources and ecological risk assessment of polycyclic aromatic hydrocar-bons in sediments from Xidayang Reservoir, Hebei Province," Journal of Lake Sciences, vol. 23, no. 5, pp. 701-707, 2011.

[62] C.-W. Fan, T.-N. Yang, and S.-J. Kao, "Characteristics of sedimentary polycyclic aromatic hydrocarbons (PAHs) in the subtropical Feitsui Reservoir, Taiwan," Journal of Hydrology, vol. 391, no. 3-4, pp. 217-222, 2010.

[63] P. Baumard, H. Budzinski, P. Garrigues, J. C. Sorbe, T. Burgeot, and J. Bellocq, "Concentrations of PAHs (polycyclic aromatic hydrocarbons) in various marine organisms in relation to those in sediments and to trophic level," Marine Pollution Bulletin, vol. 36, no. 12, pp. 951-960, 1998.

[64] H. Peng, Y. Yang, M. Liu, Y. Li, Q.-D. Zhang, and G. Yang, "Distribution and origin of polycyclic aromatic hydrocarbons in sediments of the reaches of Huaihe River (Huainan to Bengbu)," Environmental Science, vol. 31, no. 5, pp. 1192-1197, 2010.

[65] R. M. Harrison, D. I. T. Smith, and L. Luhana, "Source apportionment of atmospheric polycyclic aromatic hydrocarbons collected from an urban location in Birmingham, UK," Environmental Science \& Technology, vol. 30, no. 3, pp. 825-832, 1996.

[66] N. Rajput, A. A. Pyari, M. K. Saini, K. M. Kumari, and A. Lakhani, "Assessment of PAH toxicity and mutagenicity in emissions from coal and biofuel combustion," Journal of Environmental Science and Engineering, vol. 52, no. 3, pp. 185-192, 2010.

[67] R. Zhang, F. Zhang, and T.-C. Zhang, "Sedimentary records of PAHs in a sediment core from tidal flat of Haizhou Bay, China," Science of the Total Environment, vol. 450-451, pp. 280-288, 2013.

[68] Z. Guo, T. Lin, G. Zhang, Z. Yang, and M. Fang, "Highresolution depositional records of polycyclic aromatic hydrocarbons in the central continental shelf mud of the East China Sea," Environmental Science \& Technology, vol. 40, no. 17, pp. 5304-5311, 2006.

[69] A. H. Miguel and P. A. P. Pereira, "Benzo(k)fluoranthene, benzo(ghi)perylene, and indeno(1, 2, 3-cd)pyrene: New tracers of automotive emissions in receptor modeling," Aerosol Science and Technology, vol. 10, no. 2, pp. 292-295, 1989. 

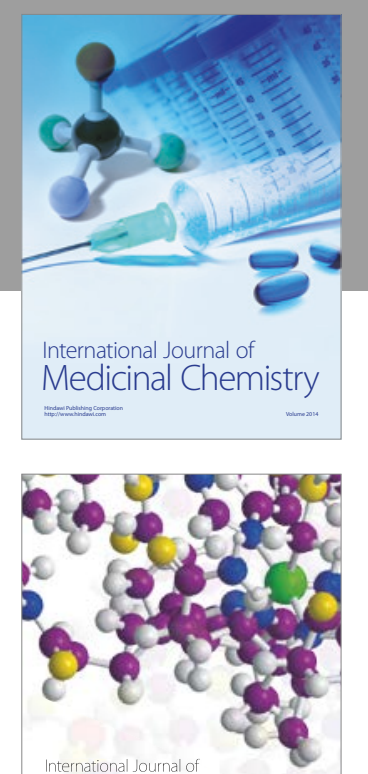

Carbohydrate Chemistry

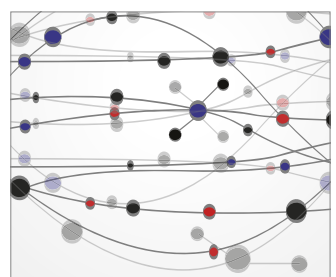

The Scientific World Journal
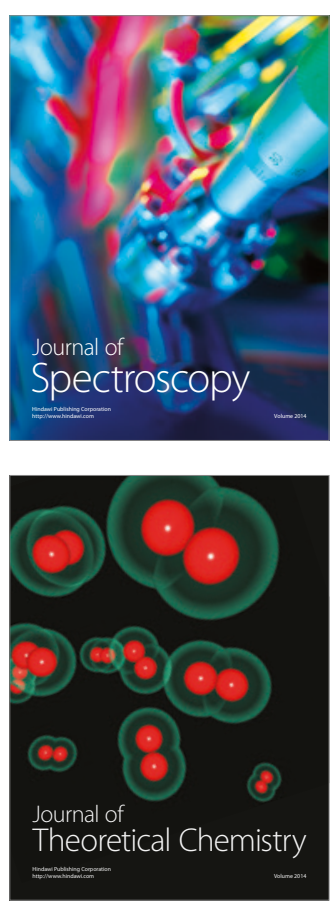
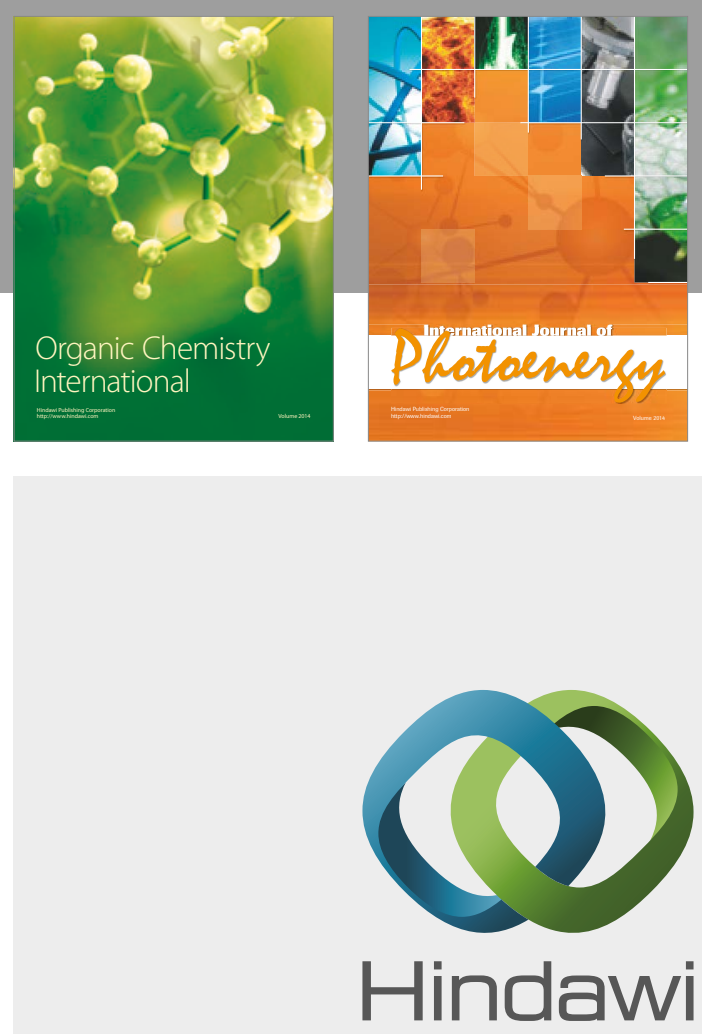

Submit your manuscripts at

https://www.hindawi.com

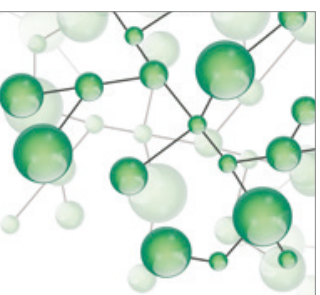

International Journal of

Inorganic Chemistry

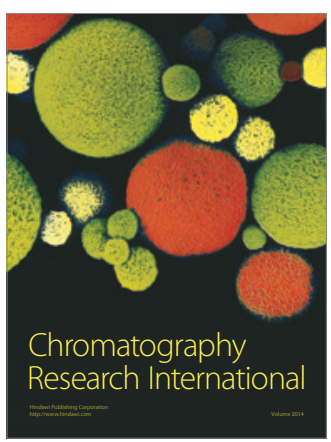

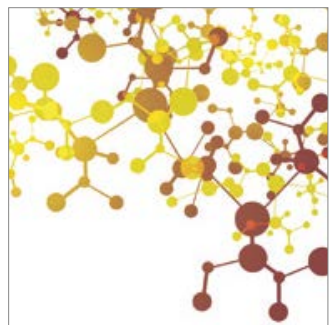

Applied Chemistry
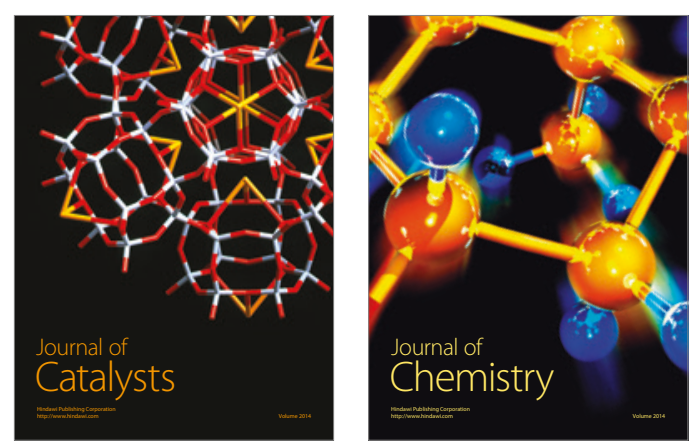
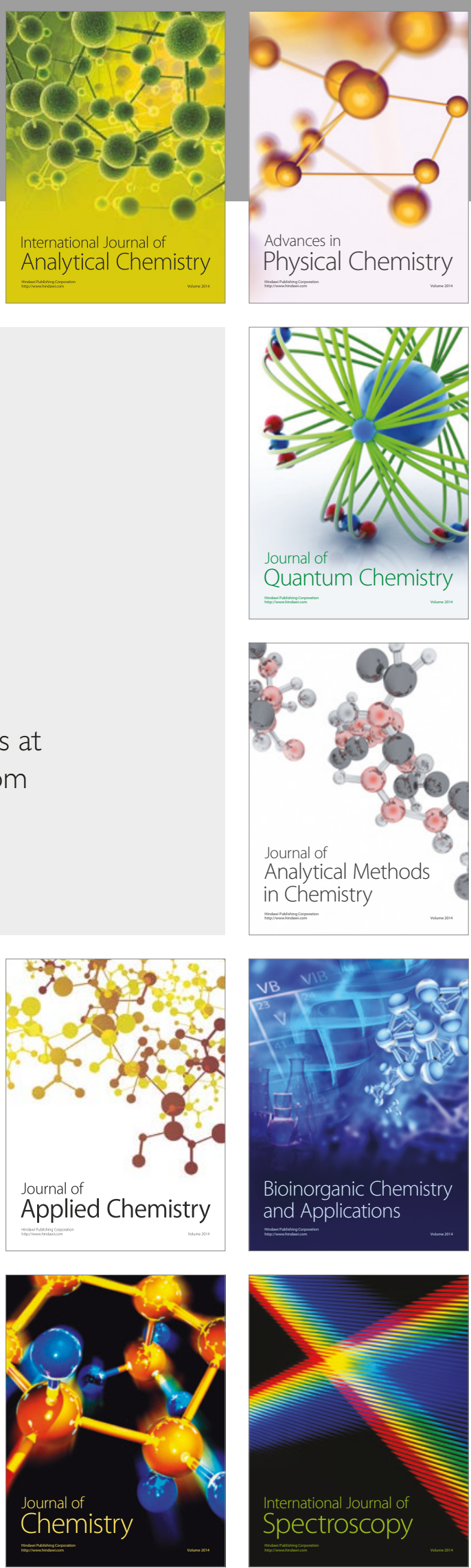